\title{
TAXONOMY AND STRATIGRAPHIC DISTRIBUTION OF THE AMMONITE SCHLOENBACHIA NEUMAYR, 1875 FROM THE BOHEMIAN CRETACEOUS BASIN
}

\author{
MARTIN KOŠŤÁK' ${ }^{1, *}$, JAN SKLENÁŘ², MARTIN MAZUCH' ${ }^{1}$, STANISLAV ČECH ${ }^{3}$ \\ 'Institute of Geology and Palaeontology, Faculty of Science, Charles University, Albertov 6, 12843 Praha 2, the Czech Republic; e-mail: \\ martin.kostak@natur.cuni.cz,martin.mazuch@ natur.cuni.cz. \\ 2 Department of Palaeontology, National Museum, Václavské náměstí 68, 11000 Praha 1, the Czech Republic; e-mail: jan_sklenar@nm.cz. \\ ${ }^{3}$ Czech Geological Survey, Klárov 3/131, 11821 Praha 1, the Czech Republic; e-mail: stanislav.cech@geology.cz. \\ ${ }^{*}$ corresponding author
}

Košt’ák, M., Sklenáŕ, J., Mazuch, M., Čech, S. (2019): Taxonomy and stratigraphic distribution of the ammonite Schloenbachia NeumaYr, 1875 from the Bohemian Cretaceous Basin - Fossil Imprint, 75(1): 64-69, Praha. ISSN 2533-4050 (print), ISSN 2533-4069 (on-line).

\begin{abstract}
Only two specimens of the ammonite genus Schloenbachia have hitherto been recorded from the Bohemian Cretaceous Basin (BCB). While the first specimen was originally described by Dr. J. Soukup in the 1970s, the other one was discovered in an older collection of the Faculty of Science, Charles University in Prague in 2018. Recently, both specimens were systematically investigated and interpreted as Schloenbachia lymensis, a new ammonite species for the BCB. The stratigraphic distribution of $S$. lymensis as well as the palaeobiogeography of this taxon are discussed in this paper.
\end{abstract}

Key words: Upper Cenomanian, Bohemian Cretaceous Basin, ammonites, Schloenbachia lymensis

Received: March 1, 2019| Accepted: May 29, 2019 | Issued: August xx, 2019

\section{Introduction}

The Bohemian Cretaceous Basin (BCB) represents a relic of a sedimentary area (Text-fig. 1) linking the Boreal and the Tethyan Realms (Wiese et al. 2004). Therefore, the presence of faunas typical for both palaeobiogeographic units may indicate palaeoceanographic changes in Central Europe. Although not pivotal, even cephalopods are valuable indicators of these changes. Representatives of the ammonite genus Schloenbachia NeUmaYR, 1875 are widely distributed geographically (from Greenland, UK, France, Germany, Poland to Kara sea - Russia in the north and Iran in the south), especially in northern Cretaceous basins. On the contrary, they are virtually unknown from the southern Tethys (i.e. North Africa, Madagascar, Western Mediterranean). However, they are reported from several sites of the Northern Tethys - Southern France, Crimea, Turkmenistan, Iran (see Wilmsen and Mosavinia 2011, Kennedy 2013, for more details). In this respect, the genus Schloenbachia should be considered more as a Boreal taxon with peri-Tethyan occurrences (Wright and Kennedy 2015).

Morphologically, Schloenbachia species belong to the most variable taxa within ammonites (Wilmsen and Mosavinia 2011, Kennedy 2013, Wright and Kennedy 2015) with long stratigraphic ranges (Kennedy 2013). The stratigraphic distributions as well as taxonomy of this group is still under discussion (Wright and Kennedy 2015, Machalski 2018, and others). While the Lower Cenomanian representatives are referred to Schloenbachia varians (J. SowERBY, 1817) with numerous intergrading variants called forms (Kennedy 2013 - see discussion below), the Middle Cenomanian species belong mostly to $S$. coupei (BrongNIART, 1822 ) and the youngest, variable, and less known taxon $S$. lymensis SPATH, 1926 is the Upper Cenomanian species.

Within the BCB, a single record of Schloenbachia varians trituberculata SPATH, 1926 was documented by Soukup (1971) from organodetritic limestones transgressively overlaying neoproterozoic gneisses in the Plaňany quarry near Kolín. A relatively well preserved specimen (stored in the National Museum, Prague as item NM-O 1801) which was investigated by Soukup in great depth and is discussed herein within modern taxonomic and stratigraphic concepts. A new record of the Schloenbachia genus comes from locality Slaný. It was found in the older collections at the Faculty of Science, Charles University, Prague in 2018. According to the lithology of the sample and with respect to newly interpreted strata of the Pecínov Member of the Peruc-Korycany Formation (Košt’ák et al. 2018), we assign this record to the Upper Cenomanian, the Metoicoceras geslinianum Zone (see discussion below). Both these specimens, that of Soukup (1971) and the specimen from Slaný described herein, are interpreted as S. lymensis. 


\section{Geological and stratigraphical settings}

Detailed information on geological setting and stratigraphy of the Plan̆any quarry and the source layer of the specimen itself is given in Soukup (1971, and references therein). The "pocket" filled with organodetritic limestone originally described by Soukup (1971) was destroyed during exploitation in 1969. Later, occasionally multiple sections of the quarry situated in similar or different topographic levels were studied by numerous authors (Žitt and Nekvasilová 1996, Marek et al. 2013, Žítt and Vodrážka 2013). A detailed study focused on post-Cenomanian sedimentary history with special respect to Plaňany elevation morphology was published by Žítt et al. in 2015. The exact stratigraphic position of organodetritic limestones and correlation with other sections in the quarry is complicated also due to frequent gaps in sedimentation, wave sweep action, and faunal reworking at the CenomanianTuronian boundary. The accompanying fauna is listed by Soukup (1971) including also cephalopods Scaphites equalis (J. Sowerby, 1913) and Sciponoceras baculoide (Mantell, 1822) and relatively numerous rudists. According to Soukup (1971), rostra of belemnite Praeactinocamax plenus (BLAinville, 1827) had not been recorded together with the Schloenbachia specimen. Therefore, Soukup (1971) assigned these strata to the Upper (or Middle) Cenomanian, as the so called "Plenus Zone" was at that time incorrectly considered as a transitional Zone between the Cenomanian and the Turonian in the BCB (e.g. Zázvorka 1965, etc.). Based on systematic re-interpretation of Soukup's specimen, we suggest more likely an Upper Cenomanian (probably Calycoceras guerangeri through the Metoicoceras geslinianum zones) occurrence at the Plaňany quarry. A newly discovered specimen of Inoceramus pictus pictus J. SOWERBY, 1829 in Soukup's original material supports this interpretation.

The specimen from the locality Slaný comes from the off-shore grey to dark grey mudstone, typical for the Pecínov Member of the Peruc-Korycany Formation (Uličný et al. 1997). The Pecínov Member is divided into four units

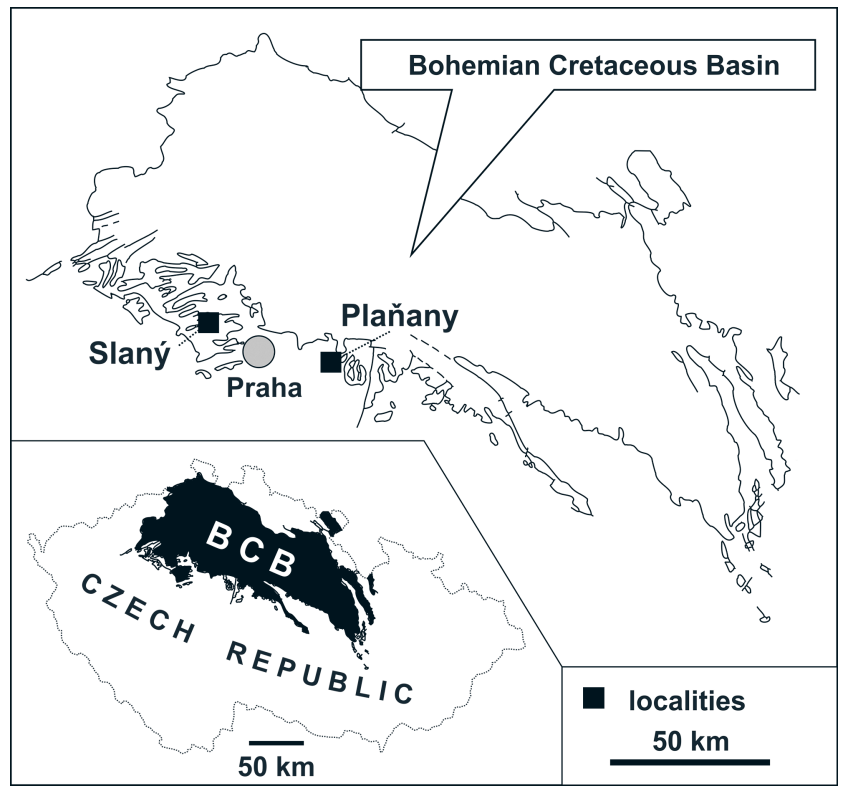

Text-fig. 1. The map of the BCB showing position of localities with recorded specimens. (for details see Uličný et al. 1997, Košták et al. 2018) and especially the lower part (including units P1-2 sensu Košt'ák et al. 2018) is biostratigraphically well calibrated by ammonites. The sharp erosional base of the P2 unit is overlain by glauconitic sandy siltstone. The studied specimen (preserved in the sediment; Text-fig. 2e) shows no glauconite content typical for the P2 unit (its lower part respectively $\mathrm{P} 2 \mathrm{a}-\mathrm{d}$ ) at Pecínov. Therefore, the highest probability is that the stratigraphic level of S. lymensis from Slaný corresponds most likely to the equivalent of the P1 unit at Pecínov - i.e. the lower part of the Metoicoceras geslinianum Zone. The glauconite lacking upper part of the $\mathrm{P} 2$ unit (P2e - upper part of the Metoicoceras geslinianum Zone and the uppermost part of the Sciponoceras gracile/Euomphaloceras septemseriatum Subzone) is similar in lithology. However, this stratigraphic level seems to be rather unlikely, as the last occurrence (LO) of S. lymensis is reported from the Praeactinocamax plenus Zone (Marcinowski 1972, 1974, Marcinowski and Radwanski 1989) - i.e. strata corresponding to the glauconitic lower part of P2 (Košt'ák et al. 2018). Therefore, we assume the stratigraphic position for the specimen to be the lower part of the Metoicoceras geslinianum Zone, below the Sciponoceras gracile/Euomphaloceras septemseriatum Subzone within the BCB.

\section{Systematic palaeontology}

\author{
Order Ammonoidea ZiTTEL, 1884 \\ Suborder Ammonitina Hyatт, 1889 \\ Superfamily Hoplitoidea H. Douvillé, 1890
}

Family Schloenbachiidae PArona et Bonarelli, 1897

Genus Schloenbachia NeUMAYR, 1875

Type species. Ammonites varians J. Sowerby, 1817, p. 169, pl. 176; subsequent designation by Douvillé (1890: 290).

\section{Schloenbachia lymensis SPATH, 1926 \\ Text-fig. $2 \mathrm{a}-\mathrm{g}$}

1853 Ammonites varians var. subtuberculata; Sharpe, p. 22, pl. 8 , fig. 8 .

non 1853 Ammonites coupei var. tuberculata MANTELL; Sharpe, p. 24, pl. 8, fig. 4.

1926 Schloenbachia lymensis; Spath, pp. 426, 430.

1971 Schloenbachia varians trituberculata SРAтH; Soukup, p. 77, figs $1-2$, pl. 1 .

1985 Schloenbachia varians trituberculata Spath; Svoboda, p. 26.

1998 Schloenbachia spp.; Kaplan et al., p. 109.

2002 Schloenbachia lymensis SРATH; Wright and Kennedy, p. 185 , pl. 31, figs 3-4.

2004 Schloenbachia varians trituberculata; Košták et al., p. 515.

2005 Schloenbachia lymensis SPAтH, 1926a; Gale et al., p. 466, fig. $12 \mathrm{f}$.

2013 Schloenbachia lymensis Spath, 1926b; Kennedy, p. 464, fig. 11.

2015 Schloenbachia lymensis SpatH; Wright and Kennedy, p. 450, figs 179-180, pls 141-145. (with complete synonymy)

M a t e ri a l. Two specimens No. NM-O 1801 (National Museum, Prague) and No. 2310/2819 (Chlupáč's Museum of Earth History, Faculty of Sciences, Charles University, Prague). 

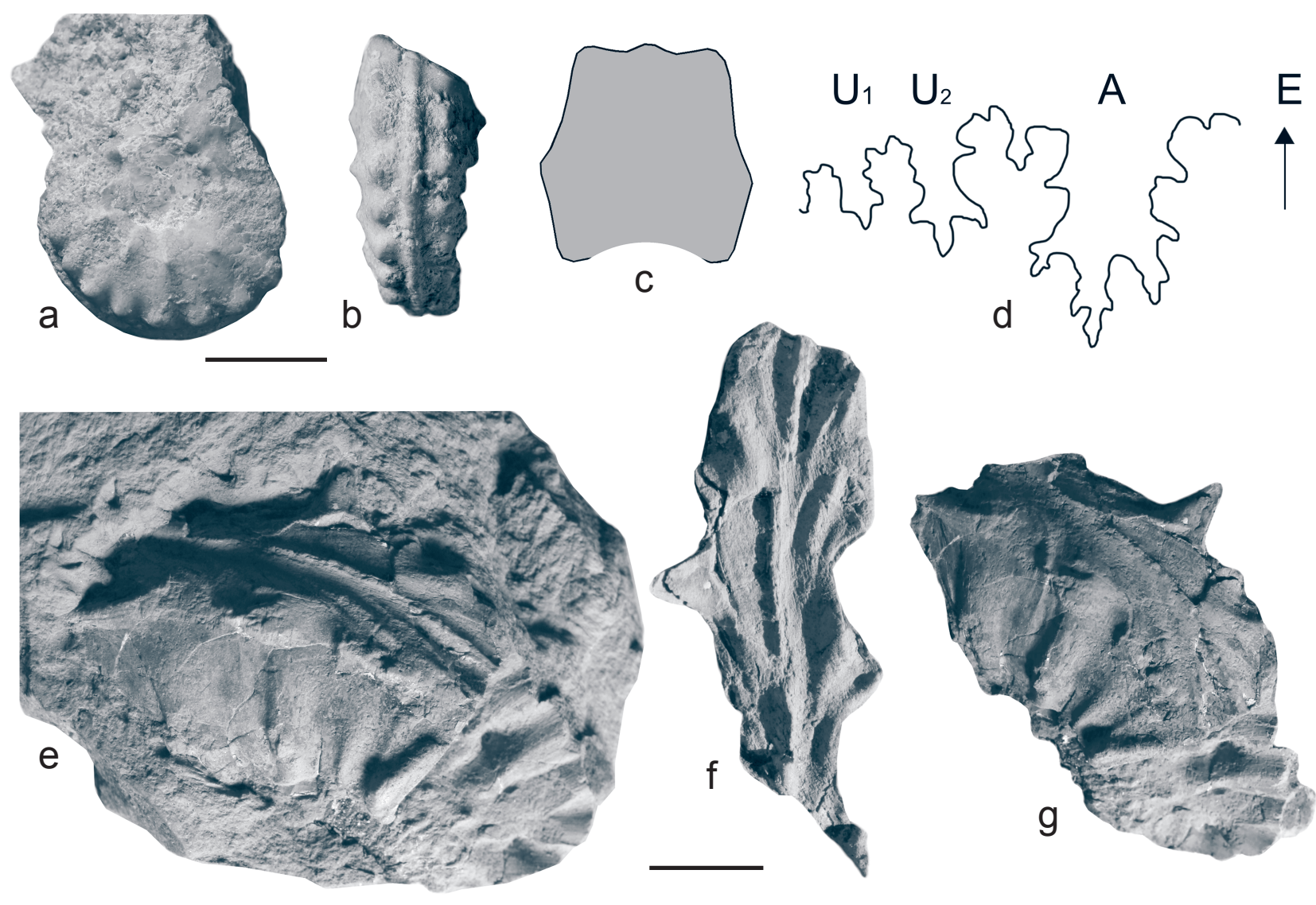

Text-fig. 2. a-g. Schloenbachia lymensis SPATH, 1926. a-d. S. lymensis from the Plan̆any quarry. a. Lateral view. b. Ventral view. c. Whorl section (improved from Soukup 1971). d. Suture line (adopted from Soukup 1971; improved). E - external lobe, A adventive lobe, U1 and U2 - umbilical lobes. e-g. S. lymensis from the locality Slaný. e, g. Ventro-lateral view showing larger clavi modified into spines closely to the aperture. f. Ventral view. Scale bars equal $10 \mathrm{~mm}$.

Description. For detailed description of specimen S. lymensis from Plaňany quarry see Soukup (1971). The additional record from Slaný represents a larger adult specimen (?macroconch) with the majority of the body chamber preserved (internal mould) including the aperture. The preserved slightly compressed fragment consists of a $70 \mathrm{~mm}$ long and $30 \mathrm{~mm}$ high part of the whorl. The siphonal keel is well developed, connecting the chevronlike structures resulting from the constriction of the body chamber. The umbilical bullae are coarser and they give a rise to prorsiradiate ribs, coarser in the inner part. Unusual ventrolateral spines (i.e. modified ventrolateral clavi) are well developed in the last three main ribs of the body chamber. The suture line observable in Soukup's original specimen from Plaňany (Text-fig. 2d) corresponds well to the specimen figured by Wright and Kennedy (2015: textfig. $180 \mathrm{~B})$.

R e m ark s. Spath's (1926) holotype corresponds with our specimen from Plañany in the majority of morphological aspects. The only difference are the remarkable coarser lateral tubercles in the second specimen (loc. Slaný; see Text-fig. 2e, g). According to Wright and Kennedy (2015), $S$. lymensis is analogous to $S$. coupei forma trituberculata (= S. varians trituberculata sensu Soukup 1971) with some differences such as the larger adult size (specimen from Slaný), finer inner ribs, missing lateral and umbilical tubercles typical for $S$. coupei (compare with the specimen from Plaňany), disappearing of the lateral tubercles (partly seen in the Plaňany specimen) and loss of the ventrolateral clavi in adult specimens of $S$. lymensis. Sharpe's specimen (1853: 24, pl. 8, fig. 4) included in the synonymy list by

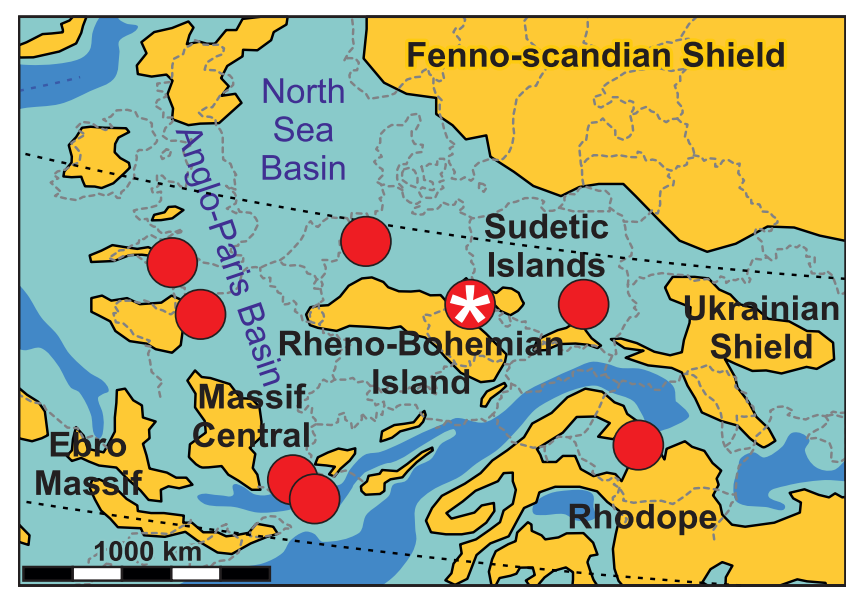

Text-fig. 3. Palaeogeographic distribution of Schloenbachia lymensis (red dots) in the Upper Cenomanian Calycoceras guerangeri through the Metoicoceras geslinianum Zones. Light blue - shallow epicontinental sea, dark blue - deep marine settings, yellow - land. * asterisk - occurrence in the BCB (modified after Wilmsen 2012). 
Soukup (1971) belongs to S. lymensis according to Wright and Kennedy (2015).

Wright and Kennedy (2015) recognized five forms of S. lymensis: lymensis sensu stricto, simplicosta, lautiforme, flexicosta and lissa based on differences in morphology. Both specimens from the $\mathrm{BCB}$ correspond to the forma lymensis sensu stricto. Additionally, in the specimen from Slaný, we observed unusual ornamentation consisting of markedly developed ventrolateral clavi slightly modified as spines. This morphological feature modifies to some extent the opinion (Wright and Kennedy 2015) that the loss of the ventrolateral clavi occurred in mature specimens of $S$. lymensis.

The specimen from Slaný was originally labelled as "Ammonites dentato-carinatus Roem.". A taxon corresponding to the Coniacian genera Barroisiceras DE Grossouve, 1894 or Santonian Texasia ReEside, 1932. The keel in our specimen does not show any serration or clavi typical for these taxa. Moreover, no sediments of the same age have been recognized in the vicinity of Slaný town.

Stratigraphic and geographic distributions. According to Kennedy (2013) and Wright and Kennedy (2015), the FO of S. lymensis is in the Middle Cenomanian terminal Acanthoceas jukesbrownei Zone and acme in the Upper Cenomanian Calycoceras guerangeri Zone. The LO is reported from the Praeactinocamax plenus Zone within the Metoicoceas geslinianum Zone. The occurence in the $\mathrm{BCB}$ falls into the Calycoceras guerangeri through the Metoicoceras geslinianum Zones.

This species is known from England (Dorset, Lyme Regis, Shapwick Grange, Bincombe, Eastbourne), France (Seine-Maritime, Rouen, Craie, Les Lattes, Alpes-deHaute), Germany (Münster Basin), Poland (Holy Cross Mts), Romania (Haţeg) (Wright and Kennedy 2015), and the $\mathrm{BCB}$ - this paper (Text-fig. 3).

\section{Discussion}

As noticed by Wilmsen and Mosavinia (2011), Kennedy (2013), Wright and Kennedy (2015) and others, the systematics and taxonomy in such a variable taxon are somewhat complicated. There are only minor differences among Schloenbachia species. Also quite long stratigraphic ranges (throughout several ammonite zones) have been reported from the Lower through the Upper Cenomanian

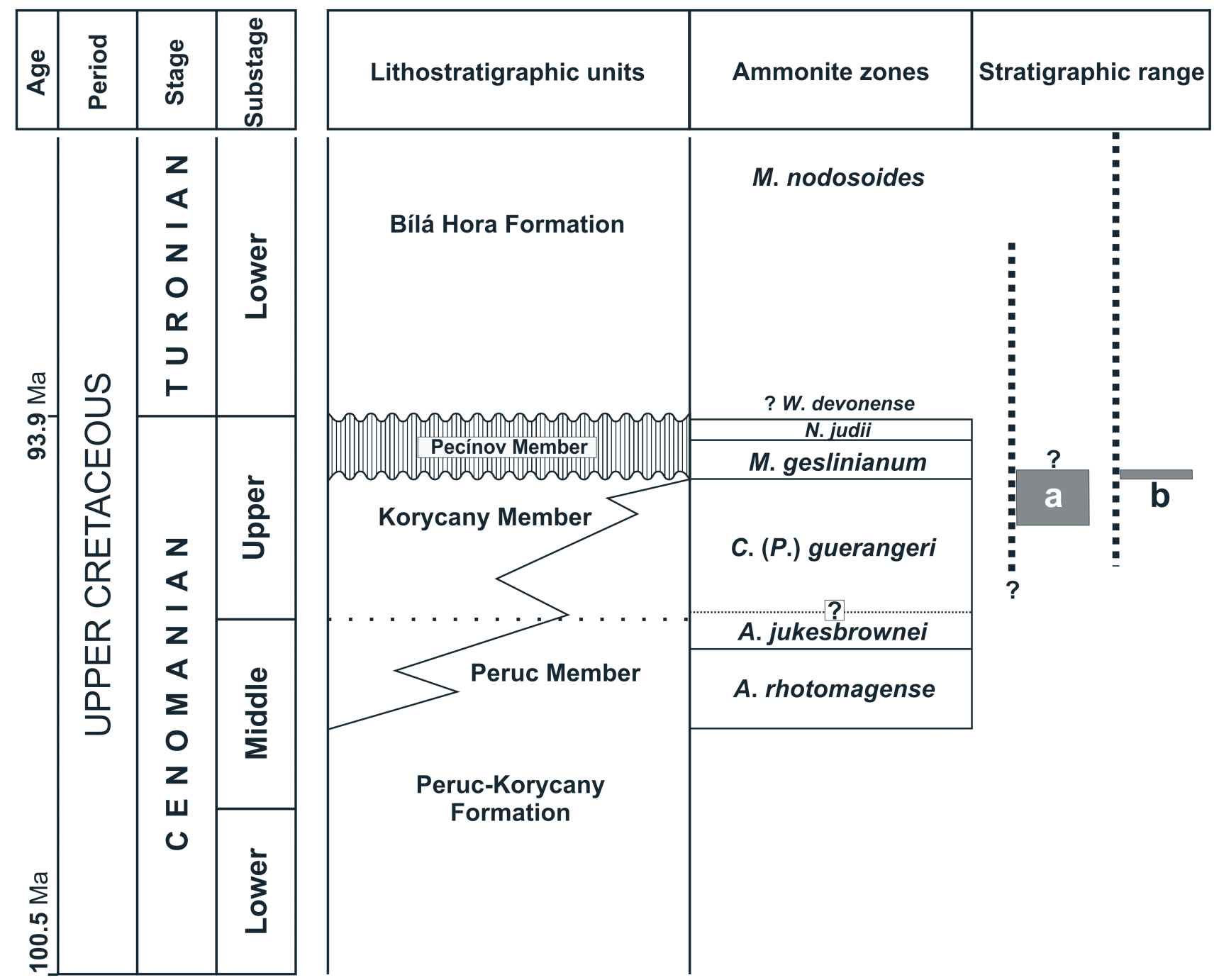

Text-fig. 4. Lithostratigraphy of the BCB and standard ammonite zonation in relation to Schloenbachia lymensis occurrence. a. Plaňany. b. Slaný. Dashed lines indicate chronostratigraphic ranges of marine strata in both localities. For detailed litho- and biostratigraphy of the Pecínov Member see Košt’ák et al. (2018). 
(Kennedy 2013). The majority of S. lymensis records falls into the Calycoceras guerangeri Zone, however, the earliest specimens were found in the Acanthoceas jukesbrownei Zone (Wright and Kennedy 2015).

Kaplan et al. (1998) report a Schloenbachia sp. record (synonymized with $S$. lymensis by Wright and Kennedy 2015) from the limestones with the Inoceramus pictus event II. - i.e. the upper part of the Calycoceras guerangeri Zone in the Münster Basin. From the same interval, S. lymensis is documented in the Hannover area (Wilmsen 2012). Other records within this zone are listed by Wright and Kennedy (2015).

The LO of the species within the Metoicoceras geslinianum Zone is reported from a relatively small number of sites (Pop and Szász 1973, Marcinowski 1974, Marcinowski and Radwanski 1989, Thomel 1992, Kaplan et al. 1998). The taxon terminates in the Praeactinocamax plenus Zone where it co-occurres with the index belemnite taxon (Marcinowski 1972, Marcinowski and Radwanski 1989).

As mentioned above, the stratigraphic level of the specimen from Slaný falls into the lower part of the Metoicoceras geslinianum Zone (Text-fig. 4), slightly below the Praeactinocamax plenus Zone.

In the vicinity of Slaný, the lowermost part of the Metoicoceras geslinianum Zone is characterized by inoceramid species Inoceramus pictus J. SOWERBY, 1829, Inoceramus cf. bohemicus LEONHARD, 1897 and Inoceramus sp. aff. Mytiloides praeturonicus TRÖGER, 2015 as was also documented in Pecínov quarry (Košták et al. 2018). This is probably the level of Inoceramus pictus - Event III of Kaplan and Best (1985) and Diedrich (2010) in the lowermost part of the Metoicoceras geslinianum Zone in the Münster Basin.

\section{Conclusions}

We have summarized the record of a rare hoplitoid ammonite of the genus Schloenbachia - S. lymensis in the BCB. Additionally, the occurrence of S. lymensis in the Metoicoceras geslinianum Zone (specimen from Slaný) i.e. slightly below the LO of the taxon, has been confirmed. The specimen from Plan̆any may fall into the Metoicoceras geslinianum Zone and/or the Calycoceras guerangeri Zone. The presence of Schloenbachia ammonites in the BCB suggests the Boreal faunal influence in the Calycoceras guerangeri-Metoicoceras geslinianum zones. Subsequently, S. lymensis raises ammonite diversity within the Metoicoceras geslinianum Zone in the BCB.

\section{Acknowledgements}

Lenka Váchová (National Museum, Prague) is gratefully acknowledged for photography. This research is supported by projects Ministry of Culture of the Czech Republic (DKRVO 2019-2023/2.III.a, National Museum, 00023272) and PROGRES Q45. We sincerely thank the journal reviewers Prof. Z. Vašíček and Dr. J. Žítt, and the executive editor J. Wagner for valuable comments on an earlier version of the manuscript.

\section{References}

Brongniart, A. (1822): Sur quelques terrains de Craie hors du Bassin de Paris. - In: Cuvier, G., Brongniart, A. (eds), Description géologique des environs de Paris, 3rd edition. Dufour et d'Ocagne, Paris, pp. 80-101.

Diedrich, C. G. (2010): Huge accumulations of Upper Cretaceous giant ammonite shells in benthic islands of the southern North Sea Basin of Central Europe. - Episodes, 33(3): 164-171.

Douvillé, H. (1890): Sur la classification des cératites de la Craie. - Bulletin de la Société Géologique de France, 18(3): 275-292.

Gale, A. S., Kennedy, W. J., Voigt, S., Walaszczyk, I. (2005): Stratigraphy of the Upper Cenomanian-Lower Turonian Chalk succession at Eastbourne, Sussex, UK: ammonites, inoceramid bivalves and stable carbon isotopes. Cretaceous Research, 26(3): 460-487. https://doi.org/10.1016/j.cretres.2005.01.006

Hyatt, A. (1889): Genesis of the Arietidae. - Memoirs of the Museum of Comparative Zoology at Harvard College, 16(3): i-xi, 1-238 + tabs I-VI, pls I-XIV.

Kaplan, U., Best, M. (1985): Zur Stratigraphie der tieferen Oberkreide im Teutoburger Wald (NW-Deutschland), Teil I: Cenoman. - Bericht des Naturwissenschaftlichen Vereins für Bielefeld, 27: 81-103.

Kaplan, U., Kennedy, W. J., Lehmann, J., Marcinowski, R. (1998): Stratigraphie und Ammonitenfaunen des westfälischen Cenoman. - Geologie und Paläontologie in Westfalen, 51: 1-236.

Kennedy, W. J. (2013): On variation in Schloenbachia varians (J. Sowerby, 1817) from the Lower Cenomanian of Kazakhstan. - Acta Geologica Polonica, 63: 443-468. https://doi.org/10.2478/agp-2013-0019

Košt’ák, M., Čech, S., Ekrt, B., Mazuch, M., Wiese, F., Voigt, S., Wood, C. J. (2004): Belemnites of the Bohemian Cretaceous Basin in a global context. - Acta Geologica Polonica, 54(4): 511-533.

Košták, M., Čech, S., Uličný, D., Sklenář, J., Ekrt, B., Mazuch, M. (2018): Ammonites, inoceramids and stable carbon isotopes of the Cenomanian-Turonian OAE2 interval in central Europe: Pecínov quarry, Bohemian Cretaceous Basin (Czech Republic). - Cretaceous Research, 87: 150-173. https://doi.org/10.1016/j.cretres.2017.04.013

Machalski, M. (2018): The Cenomanian ammonite Schloenbachia varians (J. Sowerby, 1817) from the Cambridge Greensand of eastern England: Possible sedimentological and taphonomic implications. - Cretaceous Research, 87: $120-125$.

https://doi.org/10.1016/j.cretres.2017.03.025

Marcinowski, R. (1972): Belemnites of the Actinocamax Miller, 1823, from the Cenomanian of Poland. - Acta Geologica Polonica, 22: 247-258.

Marcinowski, R. (1974): The transgressive Cretaceous (Upper Albian through Turonian) deposits of the Polish Jura Chain. - Acta Geologica Polonica, 24: 117-217.

Marcinowski, R., Radwanski, A. (1989): A biostratigraphic approach to the mid-Cretaceous transgressive sequence of the Central Polish Uplands. - Cretaceous Research, 10(2): 153-172.

https://doi.org/10.1016/0195-6671(89)90003-7 
Marek, J., Košt’ák, M., Mazuch, M., Karoušek, O. (2013): First record of a fossil chiton (Polyplacophora) from the Bohemian Cretaceous Basin (Late Cretaceous). - Folia Musei rerum naturalium Bohemiae occidentalis, Geologica et Paleobiologica, 47(1-2): 27-32. https://doi.org/10.2478/fbgp-2013-0007

Neumayr, M. (1875): Die Ammonitiden der Kreide und die Systematik der Ammonitiden. - Zeitschrift der Deutschen Geologischen Gesellschaft, 27: 854-942.

Parona, C. F., Bonarelli, G. (1897): Fossili Albiani d'Escragnolles del Nizzardo e della Ligurias occidentale [Albian fossils of d'Escragnolles of Nice and Western Ligurias]. - Palaeontographia italica, 2: 53-112. (in Italian)

Pop, G., Szász, L. (1973): Le Cénomanien de la région de Haţeg (Carpates Méridionales). - Revue roumaine de géologie, géophysique, géographie, Géologie, 17: 177196.

Sharpe, D. (1853): Description of the fossil remains of Mollusca found in the Chalk of England. Part I. Cephalopoda. - Monographs, Palaeontographical Society, London, 7(22): 1-26, pls i-x. https://doi.org/10.5962/bhl.title.62998

Soukup, J. (1971): Ein Fund von Schloenbachia varians trituberculata Spath /Mollusca, Ammonoidea/ im mittelböhmischen Cenoman. - Věstník Ústředního ústavu geologického, 46(2): 77-81.

Sowerby, J. (1817): The Mineral Conchology of Great Britain, vol. 2. - Printed by B. Meredith, London, 251 pp.

Spath, L. F. (1926): On new ammonites from the English Chalk. - Geological Magazine, 63: 77-83. https://doi.org/10.1017/S0016756800083710

Svoboda, P. (1985): Svrchní cenoman v Plaňanech u Kolína [The Upper Cenomanian at Plaňany near Kolín]. - Bohemia Centralis, 14: 25-32. (in Czech)

Thomel, G. (1992): Ammonites du Cenomanien et du Turonien du sud-est de la France, Tome 2: Considerations sur les faunes d'Ammonites Cenomaniennes et Turoniennes des Chaines Subalpines meridionales (Alpes de Haute-Provence, Alpes-Maritimes, Var). - Serre Editeur, Nice, 383 pp.

Uličný, D., Hladíková, J., Attrep, M. J., Čech, S., Hradecká, L., Svobodová, M. (1997): Sea-level changes and geochemical anomalies across the Cenomanian-Turonian boundary: Pecínov quarry, Bohemia. - Palaeogeography, Palaeoclimatology, Palaeoecology, 132: 265-285. https://doi.org/10.1016/S0031-0182(97)00055-2

Wiese, F., Čech, S., Ekrt, B., Košt’ák, M., Mazuch, M., Voigt, S. (2004): The Upper Turonian of the Bohemian
Cretaceous Basin (Czech Republic) exemplified by the Úpohlavy working quarry: integrated stratigraphy and palaeoceanography of a gateway to the Tethys. - Cretaceous Research, 25(3): 329-352.

https://doi.org/10.1016/j.cretres.2004.01.003

Wilmsen, M. (2012): Origin and significance of Late Cretaceous bioevents: examples from the Cenomanian. - Acta Palaeontologica Polonica, 57: 759-771. https://doi.org/10.4202/app.2011.0044

Wilmsen, M., Mosavinia, A. (2011): Phenotypic plasticity and taxonomy of Schloenbachia varians (J. Sowerby, 1817) (Cretaceous Ammonoidea). - Paläontologische Zeitschrift, 85: 168-184. https://doi.org/10.1007/s12542-010-0086-5

Wright, C. W., Kennedy, W. J. (2002): Ammonites. - In: Smith, A. B., Batten, D. J. (eds), Fossils of the Chalk (second ed., revised and enlarged). The Palaeontological Association, London, pp. 176-218.

Wright, C. W., Kennedy, W. J. (2015): The Ammonoidea of the Lower Chalk, Part 6. -Monographs, Palaeontographical Society, London, 169(645): 404-459. https://doi.org/10.1080/02693445.2015.11963956

Zázvorka, V. (1965): Hranice cenoman-turon a ,zóna Actinocamax plenus" v české křídě [The CenomanianTuronian boundary and "Actinocamax plenus Zone" in Bohemian Cretaceous]. - Časopis Národního muzea, Oddělení prŕírodovědovědné, 134(2): 81-84. (in Czech)

Zittel, K. A. von (1884): Handbuch der Paläontologie, I. Abtheilung. Paläozoologie, Band 2. -R. Oldenbourg, München, Leipzig, 893 pp.

Žítt, J., Nekvasilová, O. (1996): Epibionts, their hard-rock substrates, and phosphogenesis during the Cenomanian-Turonian boundary interval (Bohemian Cretaceous Basin). - Cretaceous Research, 17(6): 715-739. https://doi.org/10.1006/cres.1996.0038

Žítt, J., Vodrážka, R. (2013): Terebella phosphatica Leriche (Polychaeta) associated with phosphatic crusts and particles (Lower Turonian, Bohemian Cretaceous Basin, Czech Republic). - Cretaceous Research, 41: 111-126. https://doi.org/10.1016/j.cretres.2012.11.003

Žítt, J., Vodrážka, R., Hradecká, L., Svobodová, M., Št’astný, M., Švábenická, L. (2015): Depositional and palaeoenvironmental variation of lower Turonian nearshore facies in the Bohemian Cretaceous Basin, Czech Republic. - Cretaceous Research, 56: 293-315. https://doi.org/10.1016/j.cretres.2015.05.007 